\title{
TNF- $\alpha$-induced up-regulation of intercellular adhesion molecule-1 is regulated by a Rac-ROS-dependent cascade in human airway epithelial cells
}

\author{
Hyunju Kim ${ }^{1}$, Jung-Sun Hwang ${ }^{1}$, \\ Chang-Hoon Woo', Eun-Young Kim ${ }^{1}$, \\ Tae-Hee Kim ${ }^{1}$, Kyung-Jin Cho', Ji-Min Seo', \\ Sang-Soo Lee ${ }^{2,3}$ and Jae-Hong Kim ${ }^{1,3}$ \\ ${ }^{1}$ School of Life Sciences and Biotechnology \\ Korea University \\ Seoul 136-701, Korea \\ ${ }^{2}$ Hallym University College of Medicine \\ Chuncheon 200-740, Korea \\ ${ }^{3}$ Corresponding authors: Tel: 82-2-3290-3452, Fax: 82-2-927-9028; \\ E-mail, jhongkim @korea.ac.kr (for J.H.K.) \\ Tel: 82-33-240-5198, Fax: 82-33-252-9875; \\ E-mail, totalhip @ hallym.ac.kr (for S.S.L.)
}

Accepted 9 January 2008

Abbreviations: DPI, diphenyliodonium; ICAM-1, intercellular adhesion molecule-1; PDTC, pyrrolidine dithiocarbamate; ROS, reactive oxygen species

\begin{abstract}
Up-regulation of intercellular adhesion molecule-1 (ICAM-1) in the lung airway epithelium is associated with the epithelium-leukocyte interaction, critical for the pathogenesis of various lung airway inflammatory diseases such as asthma. However, little is known about how ICAM-1 is up-regulated in human airway epithelial cells. In this study, we show that tumor TNF- $\alpha$ induces monocyte adhesion to A549 human lung airway epithelium and also up-regulation of ICAM-1 expression. These effects were significantly diminished by pre-treatment with diphenyliodonium (DPI), an inhibitor of NADPH oxidase-like flavoenzyme. In addition, the level of reactive oxygen species (ROS) was increased in response to TNF- $\alpha$ in A549 cells, suggesting a potential role of ROS in the TNF- $\alpha$-induced signaling to ICAM-1 expression and monocyte adhesion to airway epithelium. Further, we found out that expression of $\mathrm{Rac}^{\mathrm{N17}}$, a dominant negative mutant of Rac1, suppressed TNF- $\alpha$-induced ROS generation, ICAM-1 expression, and monocyte adhesion to airway epithelium. These findings suggest that Rac 1 lies upstream of ROS generation in the TNF- $\alpha$-induced signal-
\end{abstract}

ing to ICAM-1 expression in airway epithelium. Finally, pretreatment with pyrrolidine dithiocarbamate (PDTC), an inhibitor of NF- $\mathrm{KB}$, reduced TNF- $\alpha$-induced ICAM-1 expression and both DPI and Rac ${ }^{\mathrm{N} 17}$ significantly diminished NF- $\kappa B$ activation in response to TNF- $\alpha$. Together, we propose that Rac1-ROS-linked cascade mediate TNF- $\alpha$-induced ICAM-1 up-regulation in the airway epithelium via NF-kB-dependent manner.

Keywords: intercellular adhesion molecule-1; NF$\kappa B$; rac GTP-binding proteins; reactive oxygen species; respiratory mucosa; tumor necrosis factor- $\alpha$

\section{Introduction}

Trans-airway epithelial migration of leukocyte is a critical step of host immune responses as well as inflammatory airway diseases, causing leukocytes to migration into the airway lumen (Cramer et al., 1980; Rosseau et al., 2000; Woo et al., 2003). This migration is partly due to enhanced adhesion of leukocytes onto the epithelial cells through the expression of adhesion molecules (Rosseau et al., 2000). Recent studies have revealed the relationship between the level of intercellular adhesion molecule-1 (ICAM-1) and airway hyper-responsiveness in pulmonary disease (Zhang et al., 2004). These findings suggest the feasibility of adhesion molecules as therapeutic targets in a variety of lung inflammatory diseases.

TNF- $\alpha$, a well-known pro-inflammatory pleiotropic cytokine, elicits numerous responses including proliferation, apoptosis, inflammation, and reactive oxygen species (ROS) generation (Woo et al., 2000a; Li et al., 2002). In endothelial cells, TNF- $\alpha$ leads to the enhanced expression of vascular adhesion molecule-1 (VCAM-1) and ICAM-1 (Osborn et al., 1989), thereby enabling leukocytes to enter the inflammatory sites. This process is mediated through the activation of various transcription factors. Of these factors, NF-KB is the most wellnown transcription factor regulating many target genes such as adhesion molecules, cytokines, chemokines and various enzymes (Liu, 2005; Scott et al., 2005). Rac1, a small GTPase of the Rho family, has been known to mediate multiple cellular responses such as cell adhesion, (Wung et al., 
2005), cell migration (Braga et al., 1997; Evers et al., 2000; Woo et al., 2002), actin reorganization (Hall, 1998), cell cycle progression (Olson et al., 1995; Lamarche et al., 1996; Eom et al., 2001), and arachidonic acid (AA) metabolism (Woo et al., 2000b). Moreover, recent studies suggest that ICAM-1 induction by TNF- $\alpha$ is mediated via Rac1 in endothelial cells (Wung et al., 2005).

Unlike to endothelium, the signaling mechanism in the airway epithelium for the leukocyte adhesion is less characterized although TNF- $\alpha$ was shown to induce a similar leukocyte adhesion in the pulmonary epithelial cells (Woo et al., 2005). In the present study, we examined the signaling mechanism by which TNF- $\alpha$ mediates ICAM-1 up-regulation and leukocyte adhesion to human lung airway epithelium. Our results clearly suggest that Rac1ROS-linked cascade mediate TNF- $\alpha$-induced ICAM1 up-regulation in A549 airway epithelium. Further, an activation of NF- $\mathrm{kB}$ appears to lie downstream of Rac1-ROS-cascade in the TNF- $\alpha$-signaling to ICAM-1, thus potentially mediating leukocyte adhesion to airway epithelium

\section{Materials and Methods}

\section{Chemicals and reagents}

2',7'-dichlorofluorescein diacetate (DCFDA) was obtained from Molecular probes (Eugene, OR). TNF- $\alpha$ and diphenyliodonium (DPI) were obtained from Sigma (St. Louis, MO). Pyrrolidine dithiocarbamate (PDTC) was purchased from Calbiochem (La Jolla, CA). Antibody for ICAM-1 was obtained from Santa Cruz Biotechnology (Santa Cruz, CA). All other chemicals were from standard sources and were molecular biology grade or higher. Reporter gene NF-kB-luciferase was a gift from Dr. Soo Young Lee in Ehwa Women's University (Seoul, Korea).

\section{Cell culture}

The A549 human alveolar type II epithelial cell line was obtained from the American Type Culture Collection (ATCC, CCL-185). A549 cells were maintained in RPMI-1640 supplemented with $10 \%$ heat-inactivated FBS, $0.1 \mathrm{mM}$ nonessential amino acids, $50 \mathrm{U} / \mathrm{ml}$ penicillin, and $50 \mu \mathrm{g} / \mathrm{ml}$ streptomycin at $37^{\circ} \mathrm{C}$ under a humidified $95 \% / 5 \%(\mathrm{v} / \mathrm{v})$ mixture of air and $\mathrm{CO}_{2}$. FBS, RPMI-1640, phenol red-free RPMI-1640, gentamicin and non-essential amino acids were from GibcoBRL (Gaithersburg, MD).

\section{SDS-PAGE and immunoblotting}

Protein samples were heated at $95^{\circ} \mathrm{C}$ for $5 \mathrm{~min}$ and then loaded onto $7.5 \%$ or $10 \%$ acrylamide SDSPAGE gels, followed by transfer to polyvinylidene difluoride (PVDF) membranes with a Novex wet transfer unit (for $2 \mathrm{~h}$ at $100 \mathrm{~V}$ ). The membranes were then blocked for $1 \mathrm{~h}$ with Tris-buffered saline (TBS) containing $0.05 \%(\mathrm{v} / \mathrm{v})$ Tween 20 plus $5 \%$ $(\mathrm{w} / \mathrm{v})$ nonfat dry milk, probed for $2 \mathrm{~h}$ with the primary antibody in TBS containing $0.05 \%(\mathrm{v} / \mathrm{v})$ Tween 20 plus $3 \%(\mathrm{w} / \mathrm{v}) \mathrm{BSA}$, and then for $1 \mathrm{~h}$ with HRP-conjugated secondary antibody, before visualizing with an enhanced chemiluminescence kit (ECL, Amersham Pharmacia Biotech).

\section{Cell adhesion assay}

A549 cells were grown to confluence in $35-\mathrm{mm}$ plates and then incubated in RPMI-1640 supplemented $0.5 \%$ FBS for an additional $18 \mathrm{~h}$. In addition, U937 cells were prelabeled with fluorescent Calcein-AM $\left(10 \mu \mathrm{M}, 10 \mathrm{~min}\right.$ at $\left.37^{\circ} \mathrm{C}\right)$ in phenol red-free RPMI-1640 containing 0.5\% FBS. After stimulating A549 cells with $10 \mathrm{ng} / \mathrm{ml} \mathrm{TNF}-\alpha$ or control buffer for $18 \mathrm{~h}$, the cells were washed with PBS three times and resuspended in phenol redfree RPMI-1640 containing $0.5 \%$ FBS, and the fluorescently labeled U937 cells were added $(2 \times$ $10^{6} / \mathrm{ml}$ ). After incubation for $15 \mathrm{~min}$ at $37^{\circ} \mathrm{C}$, nonadherent cells were removed by washing four times with PBS. Adhesion of U937 was observed under a fluorescence microscope (Diagnostic Instruments) and then counted.

\section{Measurement of ROS by confocal microscopy}

Intracellular $\mathrm{H}_{2} \mathrm{O}_{2}$ was measured by DCF fluorescence following the procedure of Colavitti et al. (2002). Cells were briefly grown on coverslips for 2 days and stabilized in serum-free RPMI without phenol red for an additional 2 days before exposure to TNF- $\alpha$ for the indicated times. When assessing the effect of inhibitors, cells were preincubated with inhibitors for $30 \mathrm{~min}$. To measure intracellular $\mathrm{H}_{2} \mathrm{O}_{2}$, cells were exposed for $30 \mathrm{~min}$ to the $\mathrm{H}_{2} \mathrm{O}_{2}$-sensitive fluorophore DCFDA $(5 \mu \mathrm{g} / \mathrm{ml})$, which is converted to DCF by $\mathrm{H}_{2} \mathrm{O}_{2}$, and immediately observed with a laser-scanning confocal microscope (Carl Zeiss LSM 410). DCF fluorescence was excited at $488 \mathrm{~nm}$ with an argon laser, and the evoked emission was filtered with a $515-\mathrm{nm}$ long pass filter. The fluorescence of 30 randomly selected cells was measured. Values represent means \pm SD of DCF fluorescence intensity of three independent experiments. 


\section{Transient transfection and NF-kB luciferase activity assay}

We carried out transient transfection by plating $\sim 2$ $\times 10^{5}$ cells in $60-\mathrm{mm}$ dishes for $24 \mathrm{~h}$ and then adding Lipofectamine-Plus/DNA complex prepared with $1.8 \mu \mathrm{g}$ of DNA/dish. The quantity of DNA used in each transfection was held constant by adding sonicated calf thymus DNA. To control for variations in cell number and transfection efficiency, all clones were co-transfected with $0.4 \mu \mathrm{g}$ of $\mathrm{pCMV}$ $\beta G A L$, a eukaryotic expression vector containing the Escherichia coli $\beta$-galactosidase (lacZ) structural gene under the transcriptional control of the cytomegalovirus promoter. After incubating the cells for $3 \mathrm{~h}$ with the Lipofectamine-Plus/DNA complex, the cells were rinsed with PBS before incubating in fresh RPMI-1640 supplemented with $10 \%$ FBS. Each dish of cells was then rinsed twice with PBS and lysed in $0.1 \mathrm{ml}$ of lysis solution [0.2 $M$ Tris $\mathrm{Cl}(\mathrm{pH} 7.6), 0.1 \%$ Triton $\mathrm{X}-100]$, after which the lysed cells were scraped and spun for $1 \mathrm{~min}$. The resultant supernatants were assayed for protein and $\beta$-galactosidase activity. Luciferase activity was assayed in 10- $\mu$ l samples of extract; the luciferase luminescence was counted in luminometer (Turner Design, TD-20/20) and normalized to the co-transfected $\beta$-galactosidase activity, as described elsewhere (Woo et al., 2000b; Chung et al., 2005; Shin et al., 2007). Transfection experiments were performed in triplicate with two independently isolated sets of cells, and the results were averaged.

\section{Rac1 activity assay}

Rac1 activation was measured using a GST-(PAK)PBD fusion protein that binds GTP-bound, activated Rac1 as described previously (Akasaki et al., 1999). Briefly, the fusion protein was expressed in E. coli BL21 transformed with pGEX-4T3 plasmid by isopropyl-1-thio- $\beta$-D-galactopyranoside induction and then purified by column chromatography using glutathione-Sepharose-4B. A549 cells were serum-starved for $48 \mathrm{~h}$ prior to stimulation with TNF- $\alpha$ for the indicated time periods, after which cell lysates were prepared in lysis buffer $(50 \mathrm{mM}$ HEPES, pH 7.4, $10 \mathrm{mM} \mathrm{NaF}, 75 \mathrm{mM} \mathrm{NaCl}, 1 \%$ Nonidet P-40, $1 \mathrm{mM}$ PMSF, $1 \mathrm{mM} \mathrm{Na}_{2} \mathrm{VO}_{3}$ ), centrifuged for $20 \mathrm{~s}$ at $12,000 \mathrm{~g}$, and the supernatant was incubated on ice for 3 min with the GST-(PAK)-PBD fusion protein, which had been freshly coupled to glutathione-agarose beads. Proteins complexed to the beads were recovered by centrifugation, washed twice with the lysis buffer, and resuspended in sample buffer. The proteins were resolved by $15 \%$ SDS-PAGE and transferred to PVDF membranes. The membranes were then probed with anti-Rac1 antibody (1 : 2,000 dilution) and detected using HRP-conjugated donkey antirabbit antibody and an enhanced chemiluminescence detection kit (ECL, Amersham Biosciences, Inc.).

\section{Data analysis and statistics}

Data are expressed as mean percentages of the control \pm SD. Statistical comparisons between groups were analyzed by Student's test. Values of $P<0.05$ were considered significant.

\section{Results}

\section{TNF- $\alpha$ induces monocyte adhesion to airway epithelium monolayer}

TNF- $\alpha$ has been reported to exert its pro-inflammatory effects partly due to inducing cell adhesion in endothelial cells (Osborn et al., 1989; Liu, 2005; Scott et al., 2005). We first determined whether TNF- $\alpha$ induces a similar monocyte adhesion in the lung airway epithelial cells. When A549 bronchoepithelial cells were exposed to $10 \mathrm{ng} / \mathrm{ml} \mathrm{TNF-} \alpha$, we could observe a significantly enhanced U937 monocyte adhesion to A549 cells and a maximum adhesion was detected at $18 \mathrm{~h}$ of TNF- $\alpha$ treatment (Figure 1).

\section{TNF- $\alpha$ induces ICAM-1 expression and monocyte adhesion via ROS-dependent manner}

Based on the knowledge that the expression of adhesion molecules in epithelial cells is associated with leukocyte adhesiveness, we investigated whether TNF- $\alpha$ induces the expression of ICAM- 1 in A549 airway epithelium. As shown in Figure 2A, the level of ICAM-1 expression was dramatically increased in response to TNF- $\alpha$ and remains to be induced until $24 \mathrm{~h}$ of TNF- $\alpha$ treatment. This effect was significantly suppressed by pretreatment with DPI, a NADPH oxidase-like flavoenzyme inhibitor, suggesting a possible role of ROS generation in the TNF- $\alpha$-signaling to ICAM-1 expression (Figure 2B). In addition, TNF- $\alpha$-induced U937 monocyte adhesion to A549 cells was similarly attenuated by DPI pretreatment (Figure $2 \mathrm{C}$ ). Consistent with the proposed mediatory role of ROS in the TNF- $\alpha$ signaling, the level of ROS generation was increased in response to TNF- $\alpha(10 \mathrm{ng} / \mathrm{ml})$ and we could detect the most apparent ROS fluorescence at $30 \mathrm{~min}$ exposure (Figure $3 \mathrm{~A}$ ); however, this effect was significantly diminished by pretreatment with DPI $(5 \mu \mathrm{M})$ (Figure 3B). Together, these results suggest that TNF- $\alpha$ induces ICAM- 1 expres- 
A
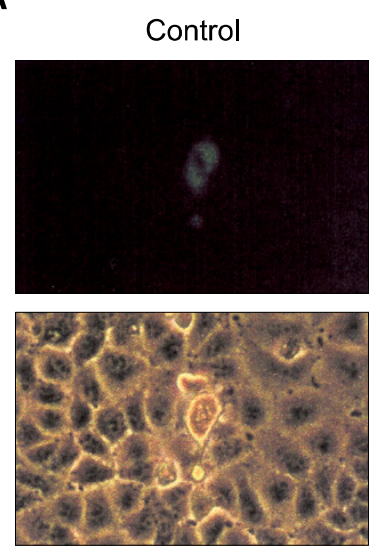
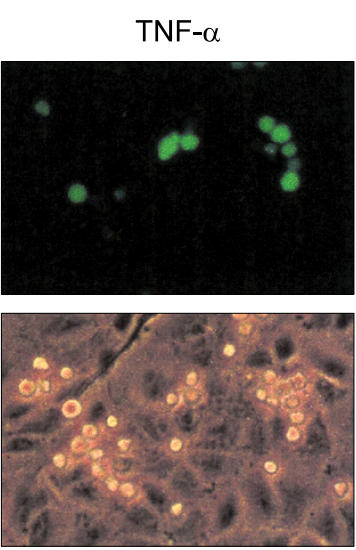

B

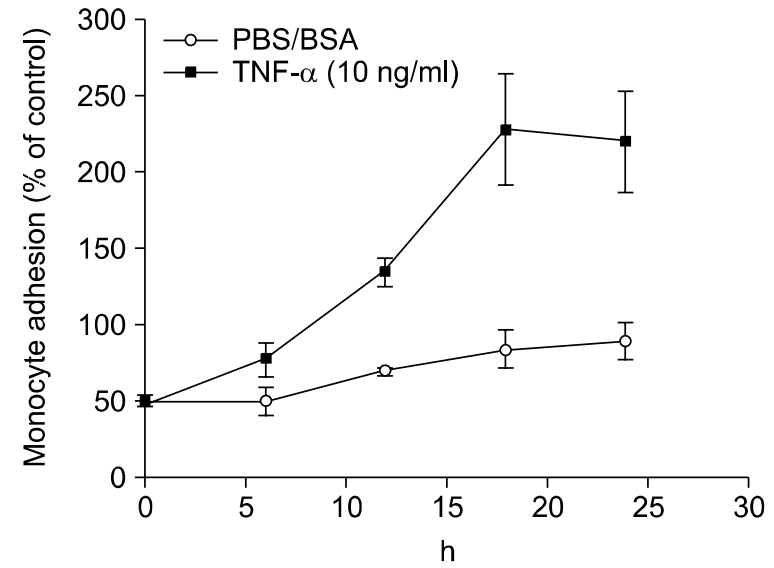

Figure 1. TNF- $\alpha$ induced monocyte adhesion to A549 lung epithelium. A549 cells were grown to confluence in 35 -mm plates and stimulated with 10 $\mathrm{ng} / \mathrm{ml}$ TNF- $\alpha$ or control buffer for $18 \mathrm{~h}$. Then, Calcein-AM-prelabled U937 monocytes were added and we incubated them for additional $15 \mathrm{~min}$. Adhesion of monocytes in response to TNF- $\alpha$ was observed using fluorescence microscopy (A) or counted after the indicated treatment times (B). Cells were counted from six different fields. Results are expressed as means \pm SD of three independent experiments.

A

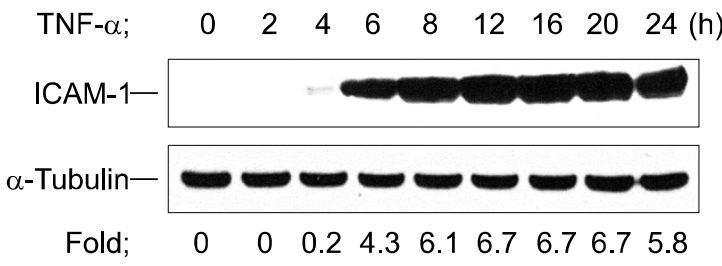

B

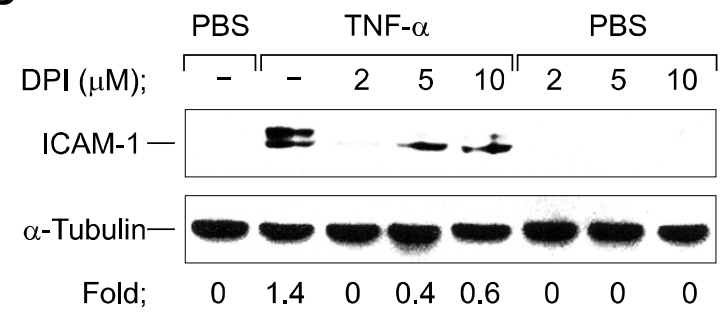

C
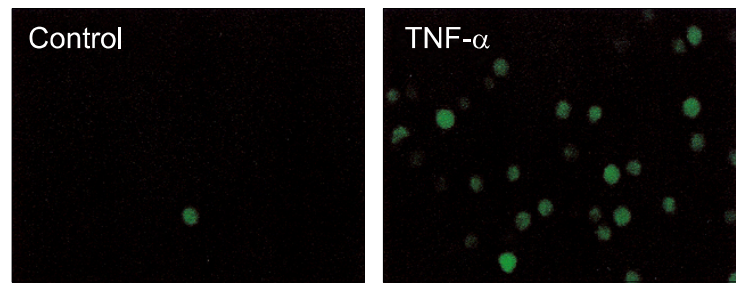

DPI

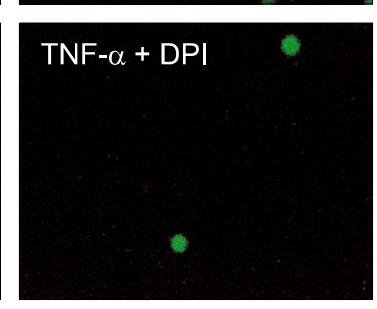

Figure 2. ROS are involved in the TNF- $\alpha$-induced monocyte adhesion to lung epithelium. (A) A549 cells were stimulated with 10 ng/ml TNF- $\alpha$ for the indicated times, or (B) cells were pretreated with DPI for $30 \mathrm{~min}$ for the indicated concentration before stimulation with TNF- $\alpha$ (10 ng/ml) or control buffer (PBS) for $12 \mathrm{~h}$. Quantification of ICAM-1 band intensity was performed by Image J version 1.24 software (developed at the National Institutes of Health, USA) and expressed in terms of fold increase of control ( $\alpha$-tubulin) for three independent experiments. Statistical significance of quantification was assessed using unpaired Student's T test $(P<0.05)$. (C) A549 cells were grown to confluence in 35-mm plates and stimulated with $10 \mathrm{ng} / \mathrm{ml}$ TNF- $\alpha$ or control buffer for $18 \mathrm{~h}$ in the absence or presence of DPI $5 \mu \mathrm{M}$, then we added Calcein-AM-prelabled U937 monocyte and incubated them for additional 15 min. Adhesion of monocytes was observed using fluorescence microscopy. These results shown are representative of at least three independent experiments.

sion and monocyte adhesion to airway epithelium via ROS generation derived from NADPH oxidaselike flavoenzyme.

\section{Involvement of Rac1 in TNF- $\alpha$-elicited ICAM-1 up-regulation}

Recent studies indicate Rac1 is involved in TNF- $\alpha$-induced ICAM- 1 expression in endothelial cells (Wung et al., 2005). Therefore, we investigated whether Rac1 plays a similar role in the TNF- $\alpha$ induced ICAM-1 expression in airway epithelial cell. A transient transfection of $\mathrm{Rac}^{\mathrm{N} 17}$, a dominant negative mutant form of Rac1, in A549 cells abrogated ROS generation in response to TNF- $\alpha$ (Figure 4A). In accordance with this result, Rac1 
A

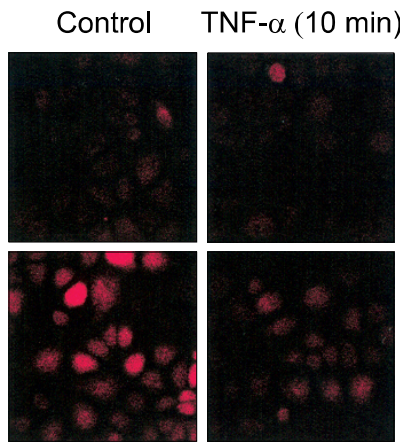

$\mathrm{TNF}-\alpha(30 \mathrm{~min}) \mathrm{TNF}-\alpha(60 \mathrm{~min})$

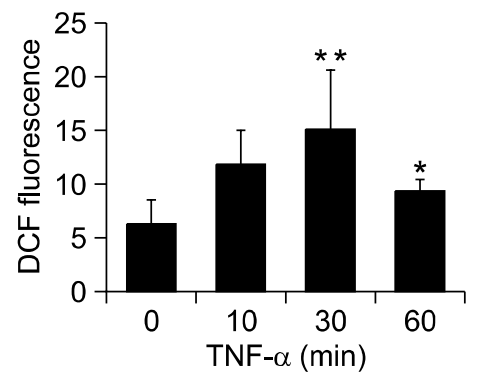

B
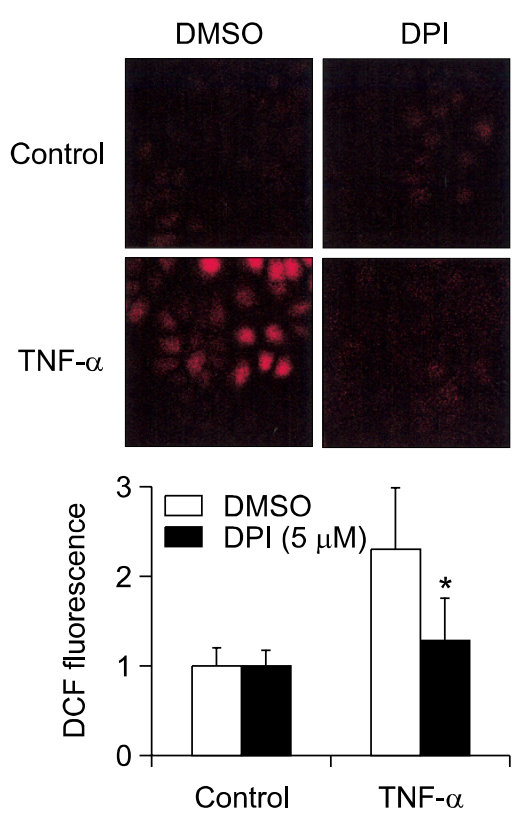

Figure 3. TNF- $\alpha$ induces ROS generation via NADPH oxidase-like flavoprotein in A549 cells. (A) A549 cells were grown to confluence on cover slips for 2 days and serum-starved with 0.5\% FBS-supplemented RPMI for additional 2 days. Then, $20 \mathrm{ng} / \mathrm{ml}$ TNF- $\alpha$ was applied for the indicated times. DCF fluorescence, reflecting relative levels of ROS (arbitrary units), was imaged using a confocal laser-scanning microscope and quantified. Statistical significance of ROS measurements was assessed using unpaired Student's test $\left({ }^{*} P<0.05\right.$, $\left.{ }^{* *} P<0.01\right)$. (B) Serum-starved A549 cells were stimulated with $20 \mathrm{ng} / \mathrm{ml} \mathrm{TNF}-\alpha$ for $30 \mathrm{~min}$ in the presence or absence of DPI $(5 \mu \mathrm{M})$. Data are expressed as means $\pm \mathrm{SD}(n=30$ cells) relative to untreated control A549 cells of three independent experiments. Statistical significance of ROS measurements was assessed using unpaired Student's test $\left({ }^{*} P<0.05,{ }^{* *} P<0.01\right)$.
A

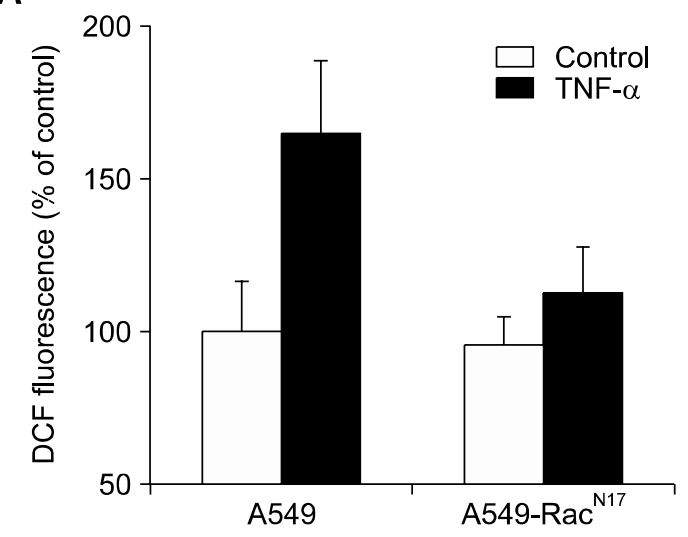

B
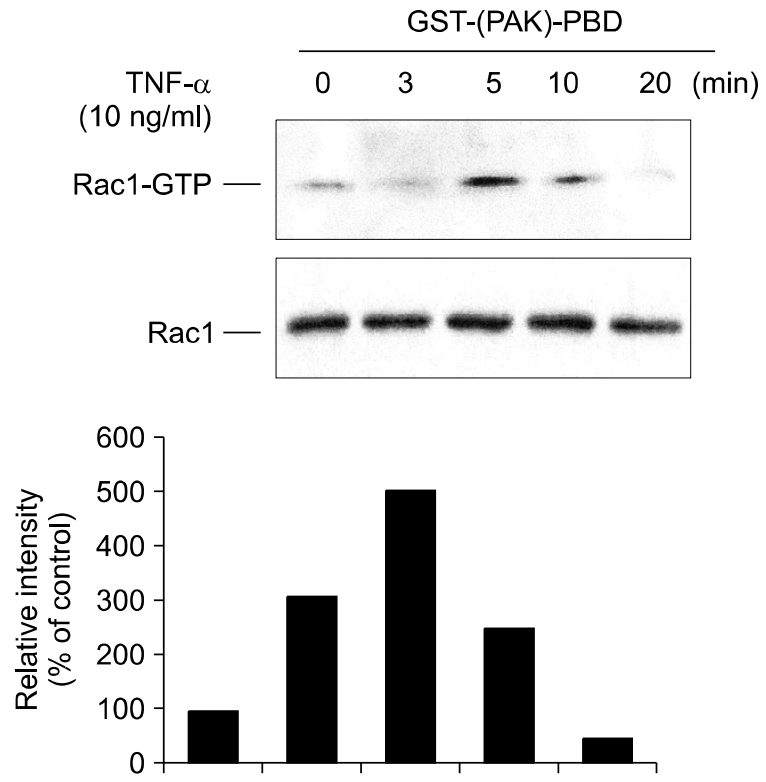

Figure 4. TNF- $\alpha$ induces ROS generation via Rac1-dependent cascade. (A) A549 cells $\left(2 \times 10^{5}\right)$ were plated in $60 \mathrm{~mm}$ plates, maintained in $10 \%$ FBS-supplemented RPMl for $48 \mathrm{~h}$ after which cells were transiently transfected with $\mathrm{pcDNA}-\mathrm{Rac}^{\mathrm{N} 17}$ utilizing Lipofectamine-Plus/DNA complex in non-supplemented RPMI. After $3 \mathrm{~h}$, cells were washed and recovered in complete medium, and then cells were exposed to $20 \mathrm{ng} / \mathrm{ml}$ TNF- $\alpha$ for 30 min with DCFDA ( $5 \mu \mathrm{g} / \mathrm{ml})$. The relative intensity of DCF fluorescence was quantified. (B) Rac1 activation was evaluated in response to TNF- $\alpha(10 \mathrm{ng} / \mathrm{ml})$ by the PAK-binding assay as described in Materials and methods. The PAK-bound Rac1-GTP was resolved by SDS-PAGE and transferred on to PVDF. Activated Rac protein, Rac1-GTP, was detected using an anti-Rac1 antibody and, as a control, total Rac protein was also determined by immunoblotting with Rac1 antibody. The relative intensity of Rac activation was measured and expressed as percentages \pm SD of three independent experiments.

activity is increased upon TNF- $\alpha$ treatment, reaching maximum levels within $5 \mathrm{~min}$ and then declined thereafter (Figure 4B). Similarly, Rac ${ }^{\mathrm{N17}}$ caused a significant reduction of both ICAM-1 expression (Figure 5A) and monocyte U937 adhesion (Figure 5B). 
A
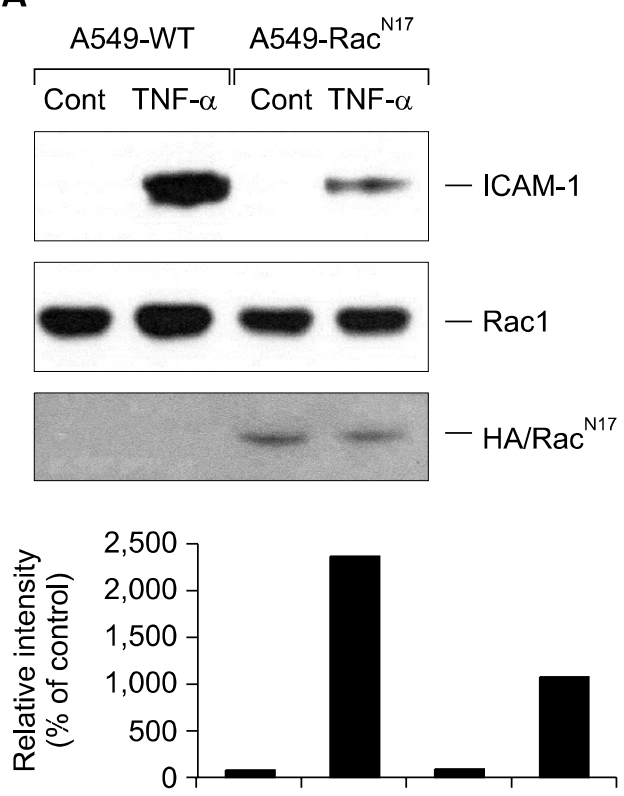

B

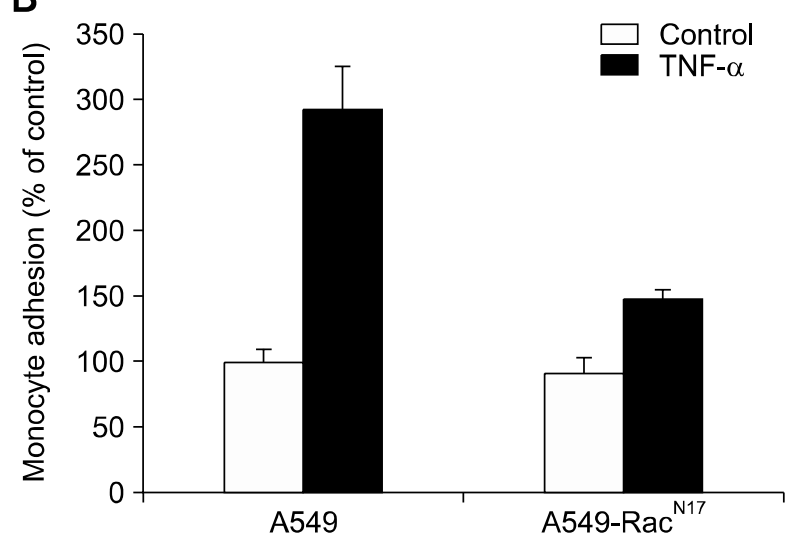

Figure 5. Rac1 is required for TNF- $\alpha$-induced ICAM-1 expression and adhesiveness. (A) A549 cells and Rac ${ }^{\mathrm{N} 17}$-transiently-transfected cells were stimulated with $10 \mathrm{ng} / \mathrm{ml}$ TNF- $\alpha$ for $12 \mathrm{~h}$. The cell lysates were subjected to immunoblot for detecting the expressions of ICAM-1, Rac1, and HA-Rac ${ }^{\mathrm{N} 17}$. The relative intensity of ICAM-1 band was measured and expressed as percentages \pm SD of three independent experiments. (B) Adhesion assays were conducted with A549 and A549 cells transfected with Rac ${ }^{\mathrm{N} 17}$ as described in Figure 1 in the presence or absence of $10 \mathrm{ng} / \mathrm{ml}$ TNF- $\alpha$. Data are expressed as means \pm SD ( $n=30$ cells) of three independent experiments.

\section{TNF- $\alpha$-induced ICAM-1 expression is through a NF-kB-dependent manner}

To further delineate the mechanism of TNF- $\alpha$ signaling to ICAM-1 expression, we examined the relevance of NF- $\mathrm{KB}$ as a representative transcription factor activated by TNF- $\alpha$. As shown in Figure $6 \mathrm{~A}, \mathrm{TNF}-\alpha$ treatment resulted in $1 \kappa \mathrm{Ba}$ degradation, which allows NF-KB to translocate into the nucleus, eventually leading to NF- $\mathrm{BB}$ activation. Similarly, TNF- $\alpha$ elevated NF-KB-luciferase activity by $\sim 8-$ fold and this augmentation was significantly diminished by DPI pretreatment (Figure 6B). Next, we investigated whether ICAM-1 expression is suppressed by PDTC, a NF-KB inhibitor. As expected, PDTC abrogated TNF- $\alpha$-induced up-regulation of ICAM-1 (Figure 6C). In addition, $\operatorname{Rac}^{\mathrm{N} 17}$ significantly inhibited TNF- $\alpha$-elicited NF- $\kappa B$ activation (Figure 6D); therefore NF-KB activation appears to be involved in the TNF- $\alpha$-signaling to ICAM-1 expression.

\section{Discussion}

In the present study, we found out that TNF- $\alpha$ induces ICAM-1 expression in the lung airway epithelial cells via a Rac1-ROS-linked cascade. In addition, DPI-sensitive NADPH-oxidase-like flavoenzyme is suggested to be involved in the ROS generation, playing a critical role in ICAM-1 expression and monocyte adhesion to airway epithelium. Finally, NF-KB activation is suggested to be situated downstream of ROS generation in the TNF- $\alpha$-signaling to ICAM-1 expression.

Induced expression of adhesion molecules, especially ICAM-1 and VCAM-1, have been reported to be associated with airway inflammatory responses (Ito et al., 2003; Lee et al., 2003; Qureshi et al., 2003). And, our previous study suggested a potential role of a PKC $\delta$-p38 kinaseVCAM-1-linked cascade in the TNF- $\alpha$-induced leukocyte adhesion and migration in the lung airway epithelium (Woo et al., 2005). Thus, we suspect that both PKC $\delta$-p38 kinase-VCAM-1 cascade and Rac1-ROS-ICAM-1 cascade somehow work together to mediate TNF- $\alpha$ signaling leading to efficient adhesion and emigration of leukocytes across airway epithelium. And, we also suspect that blockage of any cascade could lead to a significant inhibition of leukocyte adhesion to airway epithelium as shown in Figure $2 \mathrm{C}$ and $5 \mathrm{~B}$ as well as previous results (Woo et al., 2005). The detailed mechanism how TNF- $\alpha$ stimulates two independent signaling cascades to induce VCAM-1 
A

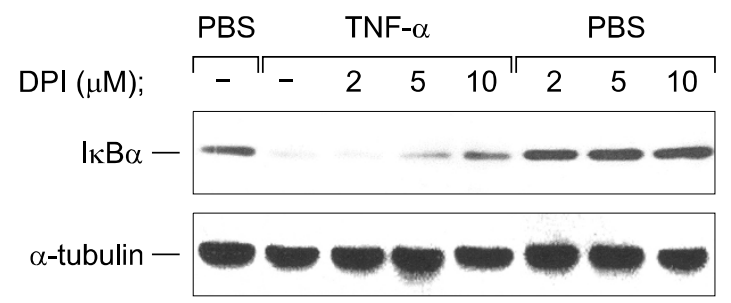

B

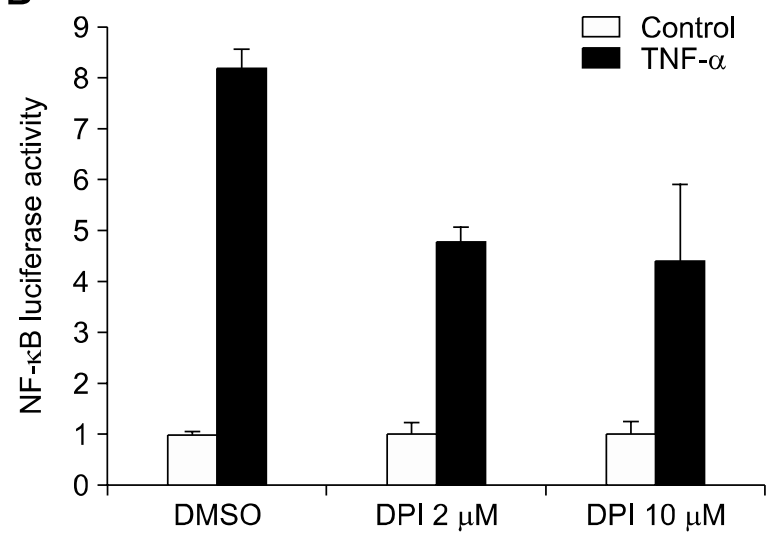

C

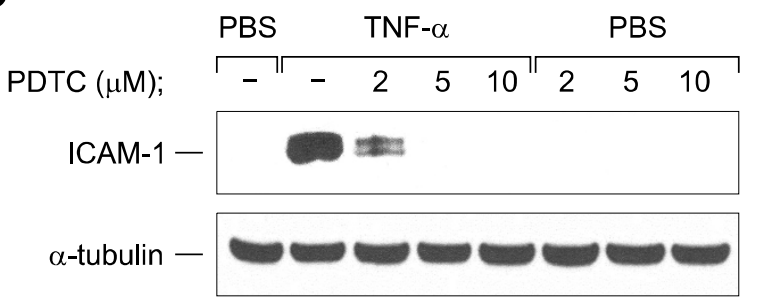

D

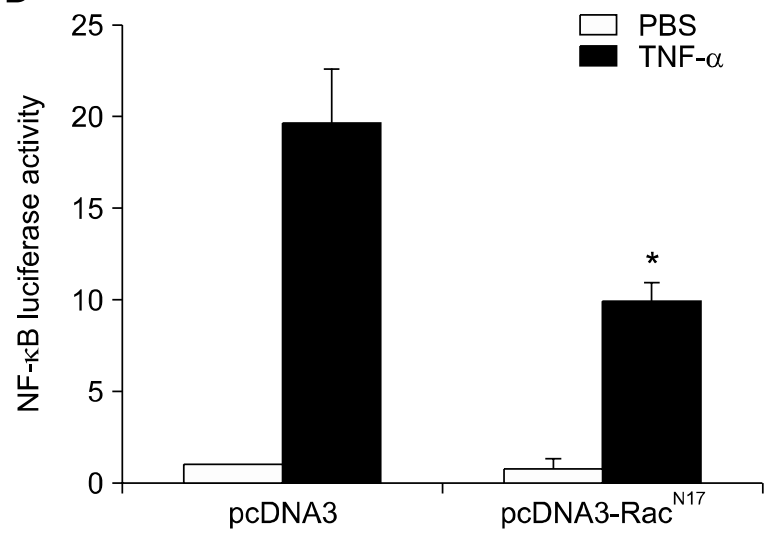

Figure 6. Rac1-ROS-linked cascade regulates TNF- $\alpha$-induced ICAM-1 expression via a stimulation of NF- $\mathrm{BB}$. A549 cells were exposed to TNF- $\alpha$ (10 $\mathrm{ng} / \mathrm{ml}$ ) for $10 \mathrm{~min}(\mathrm{~A})$ or $12 \mathrm{~h}(\mathrm{C})$ in the presence or absence of DPI (A) or PDTC $(C)$ with the indicated concentrations, respectively. Western blotting for $\operatorname{I} B \alpha(A)$ or ICAM-1(C) was carried out to determine the expression levels, respectively. (B) A549 cells were transiently transfected with a reporter gene (pNF-kB-Luc) and DPI was added for 30 min prior to the application of TNF- $\alpha$ (10 ng/ml). The relative luciferase activity was measured. (D) A549 cells were transiently co-transfected with a reporter gene (pNF-KB-Luc) along with pcDNA3 or pcDNA3-Rac ${ }^{\mathrm{N} 17}$ and the relative luciferase activity was measured using luminometer. These results shown are representative of at least three independent experiments. Statistical significance of NF- $\mathrm{KB}$ activation was assessed using unpaired Student's test $\left({ }^{*} P<0.05\right)$.

and ICAM-1 up-regulations remains to be characterized.

ROS have long been considered to be toxic and implicated in defense systems against infection (Miyachi et al., 1986; Schirmer et al., 1987). Recently, however, NADPH-oxidase (Nox) has received a lot of interest as source of ROS in cellular signaling and these Nox-derived ROS are suggested to act as specific signaling mediators in various non-phagocytic cells (Vaquero et al., 2004; Adachi et al., 2005). Although upstream regulatory mechanism for Nox activation has not been understood yet, Rac was suggested to be a crucial component for full activation of Nox (Mizrahi et al., 2005), in accordance with our observation that Rac is associated with NADPH oxidase-like flavoenzyme-derived ROS generation (Figure 4A). At this point, we do not know whether Nox is indeed involved in our signaling pathway. In addition to Noxs, mitochondria are also recognized as important ROS generating system (Hughes et al., 2005; Kamata et al., 2005) although the role of mitochondrial ROS in mediating specific signaling reactions has not been defined yet.

We observed that NF-KB stimulation plays a crucial role in the TNF- $\alpha$-induced ICAM- 1 expression and pretreatment with PDTC was shown to suppress almost completely the expression of ICAM-1 in response to TNF- $\alpha$ (Figure 6C); however pretreatment with DPI or co-transfection with $\operatorname{Rac}^{\mathrm{N}}{ }^{17}$ did not show such a drastic suppressive effect on the TNF- $\alpha$-induced NF- $\mathrm{BB}$ stimulation (showing only $\sim 50 \%$ inhibitory effect) as analyzed by luciferase assay (Figure 6B and D). Thus, there could be alternative pathways stimulating $\mathrm{NF}-\mathrm{KB}$ besides a Rac-ROS-linked cascade in response to TNF- $\alpha$ in airway epithelium. This observation is also in consistent with the result (Figure 6A) showing that TNF- $\alpha$-induced $I \kappa B \alpha$ degradation is only partially attenuated by pretreatment with DPI, again supporting a potential existence of RacROS-independent pathway.

In any event, we are quite sure that Rac-ROS cascade plays a critical role in the expression of ICAM-1 in response to TNF- $\alpha$. And although further studies are needed to examine the possible 
roles of other downstream mediators, an activation of NF- $\mathrm{KB}$ clearly lies downstream of Rac1-ROScascade in the TNF- $\alpha$-signaling to ICAM-1, thus mediating leukocyte adhesion to airway epithelium. We therefore propose that a Rac-ROS-NF-кBlinked cascade could be effective therapeutic target pathway useful for developing agents/drugs against human airway inflammatory diseases such as asthma.

\section{Acknowledgement}

This study was supported by the grants from Hallym University and Hallym University Medical Center (01-2004-06), the KICOS project (Bathel-Korea University), the Diseases Network Research Program from the Korea Ministry of Science and Technology, and also by the Korea Research Foundation Grant funded by the Korean Government (MOEHRD) (KRF-2006-311-C00123).

\section{References}

Adachi T, Togashi H, Suzuki A, Kasai S, Ito J, Sugahara K, Kawata $\mathrm{S}$. NAD(P)H oxidase plays a crucial role in PDGFinduced proliferation of hepatic stellate cells. Hepatology 2005;41:1272-81

Akasaki T, Koga H, Sumimoto H. Phosphoinositide 3-kinasedependent and -independent activation of the small GTPase Rac2 in human neutrophils. J Biol Chem 1999;274:18055-9

Braga VM, Machesky LM, Hall A, Hotchin NA. The small GTPases Rho and Rac are required for the establishment of cadherin-dependent cell-cell contacts. J Cell Biol 1997;137: 1421-31

Chung JW, Kim GY, Mun YC, Ahn JY, Seong CM, Kim JH. Leukotriene B4 pathway regulates the fate of the hematopoietic stem cells. Exp Mol Med 2005;37:45-50

Colavitti R, Pani G, Bedogni B, Anzevino R, Borrello S, Waltenberger J, Galeotti T. Reactive oxygen species as downstream mediators of angiogenic signaling by vascular endothelial growth factor receptor-2/KDR. J Biol Chem 2002;277:3101-8

Cramer EB, Milks LC, Ojakian GK. Transepithelial migration of human neutrophils: an in vitro model system. Proc Natl Acad Sci USA 1980;77:4069-73

Eom YW, Yoo MH, Woo CH, Hwang KC, Song WK, Yoo YJ, Chun JS, Kim JH. Implication of the small GTPase Rac1 in the apoptosis induced by UV in Rat-2 fibroblasts. Biochem Biophys Res Commun 2001;285:825-9

Evers EE, Zondag GC, Malliri A, Price LS, ten Klooster JP, van der Kammen RA, Collard JG. Rho family proteins in cell adhesion and cell migration. Eur J Cancer 2000;36:1269-74

Hall A. Rho GTPases and the actin cytoskeleton. Science 1998;279:509-14

Hughes G, Murphy MP, Ledgerwood EC. Mitochondrial reactive oxygen species regulate the temporal activation of nuclear factor kappaB to modulate tumour necrosis factorinduced apoptosis: evidence from mitochondria-targeted antioxidants. Biochem J 2005;389:83-9

Ito A, Miyake M, Morishita M, Ito K, Torii S, Sakamoto T. Dexamethasone reduces lung eosinophilia, and VCAM-1 and ICAM-1 expression induced by Sephadex beads in rats. Eur J Pharmacol 2003;468:59-66

Kamata H, Honda S, Maeda S, Chang L, Hirata H, Karin M. Reactive oxygen species promote TNFalpha-induced death and sustained JNK activation by inhibiting MAP kinase phosphatases. Cell 2005;120:649-61

Lamarche N, Tapon N, Stowers L, Burbelo PD, Aspenstrom $P$, Bridges T, Chant J, Hall A. Rac and Cdc42 induce actin polymerization and $\mathrm{G} 1$ cell cycle progression independently of p65PAK and the JNK/SAPK MAP kinase cascade. Cell 1996;87:519-29

Lee KS, Jin SM, Kim HJ, Lee YC. Matrix metalloproteinase inhibitor regulates inflammatory cell migration by reducing ICAM-1 and VCAM-1 expression in a murine model of toluene diisocyanate-induced asthma. J Allergy Clin Immunol 2003;111:1278-84

Li JM, Mullen AM, Yun S, Wientjes F, Brouns GY, Thrasher AJ, Shah AM. Essential role of the NADPH oxidase subunit p47(phox) in endothelial cell superoxide production in response to phorbol ester and tumor necrosis factor-alpha. Circ Res 2002;90:143-50

Liu ZG. Molecular mechanism of TNF signaling and beyond. Cell Res 2005;15:24-7

Miyachi Y, Yoshioka A, Imamura S, Niwa Y. Effect of antibiotics on the generation of reactive oxygen species. J Invest Dermatol 1986;86:449-53

Mizrahi A, Molshanski-Mor S, Weinbaum C, Zheng Y, Hirshberg M, Pick E. Activation of the phagocyte NADPH oxidase by Rac Guanine nucleotide exchange factors in conjunction with ATP and nucleoside diphosphate kinase. J Biol Chem 2005;280:3802-11

Olson MF, Ashworth A, Hall A. An essential role for Rho, Rac, and Cdc42 GTPases in cell cycle progression through G1. Science 1995;269:1270-2

Osborn L, Hession C, Tizard R, Vassallo C, Luhowskyj S, Chi-Rosso G, Lobb, R. Direct expression cloning of vascular cell adhesion molecule 1, a cytokine-induced endothelial protein that binds to lymphocytes. Cell 1989;59:1203-11

Qureshi MH, Cook-Mills J, Doherty DE, Garvy BA. TNFalpha-dependent ICAM-1- and VCAM-1-mediated inflammatory responses are delayed in neonatal mice infected with Pneumocystis carinii. J Immunol 2003;171:4700-7

Rosseau S, Selhorst J, Wiechmann K, Leissner K, Maus U, Mayer K, Grimminger F, Seeger W, Lohmeyer J. Monocyte migration through the alveolar epithelial barrier: adhesion molecule mechanisms and impact of chemokines. J Immunol 2000;164:427-35

Schirmer RH, Schollhammer T, Eisenbrand G, Krauth-Siegel $\mathrm{RL}$. Oxidative stress as a defense mechanism against parasitic infections. Free Radic Res Commun 1987;3:3-12 Scott BB, Zaratin PF, Gilmartin AG, Hansbury MJ, Colombo 
A, Belpasso C, Winkler JD, Jackson JR. TNF-alpha modulates angiopoietin-1 expression in rheumatoid synovial fibroblasts via the NF-kappa B signalling pathway. Biochem Biophys Res Commun 2005;328:409-14

Shin Y, Yoon SH, Choe EY, Cho SH, Woo CH, Rho JY, Kim J. PMA-induced up-regulation of MMP-9 is regulated by a $\mathrm{PKC} \alpha-\mathrm{NF}-\kappa \mathrm{B}$ cascade in human lung epithelial cells. Exp Mol Med 2007;39:97-105

Vaquero EC, Edderkaoui M, Pandol SJ, Gukovsky I, Gukovskaya AS. Reactive oxygen species produced by $\mathrm{NAD}(\mathrm{P}) \mathrm{H}$ oxidase inhibit apoptosis in pancreatic cancer cells. J Biol Chem 2004;279:34643-54

Woo CH, Eom YW, Yoo MH, You HJ, Han HJ, Song WK, Yoo YJ, Chun JS, Kim JH. Tumor necrosis factor-alpha generates reactive oxygen species via a cytosolic phospholipase A2-linked cascade. J Biol Chem 2000a;275:32357-62

Woo CH, Lee ZW, Kim BC, Ha KS, Kim JH. Involvement of cytosolic phospholipase A2, and the subsequent release of arachidonic acid, in signalling by rac for the generation of intracellular reactive oxygen species in rat-2 fibroblasts. Biochem J 2000b;348:525-30
Woo CH, Jeong DT, Yoon SB, Kim KS, Chung IY, Saeki T, Kim $\mathrm{JH}$. Eotaxin induces migration of RBL-2H3 mast cells via a Rac-ERK-dependent pathway. Biochem Biophys Res Commun 2002;298:392-7

Woo CH, Yoo MH, You HJ, Cho SH, Mun YC, Seong CM, Kim $\mathrm{JH}$. Transepithelial migration of neutrophils in response to leukotriene B4 is mediated by a reactive oxygen speciesextracellular signal-regulated kinase-linked cascade. J Immunol 2003;170:6273-9

Woo $\mathrm{CH}$, Lim JH, Kim JH. VCAM-1 upregulation via PKCdelta-p38 kinase-linked cascade mediates the TNFalpha-induced leukocyte adhesion and emigration in the lung airway epithelium. Am J Physiol Lung Cell Mol Physiol 2005;288:L307-16

Wung BS, Ni CW, Wang DL. ICAM-1 induction by TNFalpha and IL-6 is mediated by distinct pathways via Rac in endothelial cells. J Biomed Sci 2005;12:91-101

Zhang QG, Zheng DS, Yao YT, Zhang XH, Yu HL, Liang DP. Relationship between levels of intercellular adhesion molecule-1, interleukin- 6 and airway hyperresponsiveness in patients with allergic rhinitis. Zhonghua $\mathrm{Er} \mathrm{Bi}$ Yan Hou Ke Za Zhi 2004;39:617-20 